\title{
Intentions to Use Vasectomy Contraception: Application of Theory Planned Behavior
}

\author{
Tjahja Bintoro' ${ }^{1}$, Bhisma Murti², Endang Sutisna ${ }^{2}$, Suwarto $^{3}$ \\ ${ }^{1}$ Doctoral student, Universitas SebelasMaret, Solo, Indonesia, ${ }^{2}$ Professor Public health department, Universitas \\ SebelasMaret, Solo, Indonesia, ${ }^{3}$ Professor Agriculture department, Universitas SebelasMaret, Solo, Indonesia
}

\begin{abstract}
In Indonesia, $8 \%$ of married men use a FP method, 3\% use a modern FP method and $4 \%$ use a traditional FP method/method. The percentage of married men who use condoms (3\%) is higher than the percentage who choose vasectomy (less than 1\%). The study was conducted in the Madiun town administration using a community-based cross-sectional study design. The town is found in East Java Province, Indonesia. The total sample of this study is 323 married man with fixed disease sampling. The results showed that "attitude" $(p=0.04)$ and "perceived behavioral control" $(p=<0.01)$ are positive predictive factors of intention married man to chose vasectomy for contraception. This research has found the intention to limit the number of children affected by attitudes. Married men who participated in this study had negative attitudes towards vasectomy. In general, vasectomy is seen as one of the least preferred method of family planning and is associated with fear and weakness.
\end{abstract}

Keywords: Family planning, structural equation model, theory planned behavior, vasectomy.

\section{Introduction}

Unwanted pregnancy is an important public health problem because it deals with social and health conditions that are detrimental to mothers, children, and society as a whole. Pregnancy includes a higher incidence of abortion, late initiation and underutilization of prenatal care and low birth weight ${ }^{(1)}$. Men's involvement in contraception is considered a fact that determines men's lives. Effective participation in contraception can trigger significant individual, family, social and cultural changes ${ }^{(2)}$. In various communities, family planning and reproductive health issues are still seen as the responsibility of women. Knowledge and awareness of men and families about family planning are still relatively low. Besides, there are limitations to

\section{Corresponding Address:}

\section{Tjahja Bintoro}

P.O. Box: 57126. Doctoral student, Universitas Sebelas Maret, Ir. Sutami Street No. 36, Solo, Central Java, Indonesia

e-mail: btjahja34@student.uns.ac.id

Phone Number: +6281239870268 the acceptance and accessibility of male contraceptive services. The knowledge of urban and rural communities towards family planning programs has not yet developed optimally, although in terms of education the urban community is generally more advanced than rural communities $^{(3)}$.

Over the past decade, to increase men's involvement in reproductive health and family planning issues. Government and non-government agencies ${ }^{(4)}$ and international health organizations ${ }^{(5,6)}$ all acknowledged the need to involve men in reproductive health services and decision making and made convincing arguments that this would benefit both men and women. One way to encourage men's involvement in family planning is to give couples more contraceptive choices through the promotion of male-oriented method such as vasectomy. Vasectomy is a safe, simple and effective method ${ }^{(7)}$ which is relatively unknown and not used in most parts of the world. Although sterilization is the most widely used method of contraception worldwide, tubal ligation accounts for more than five times more procedures than vasectomy ${ }^{(8)}$.

The choice method and the use of effective contraceptive method is a complex problem that is 
influenced by various factors ${ }^{(9,10)}$. In this study, the research approach is based on the Theory of Reasoned Action (TRA), added by Theory of Planned Behavior $(\mathrm{TPB})^{(11)}$, both of which require an examination of personal and contextual influence ${ }^{(12)}$. In the case of TRA, intentions are considered to have 2 components: subjective attitudes and norms. Attitudes are beliefs that are involved in behavior that will be associated with positive outcomes (behavioral beliefs), as well as an assessment of how much a person evaluates these results (evaluation). Subjective norms consist of both beliefs about whether other individuals approve or disapprove behavior (normative beliefs), as well as a person's motivation to obey that individual (motivation to obey). TPB contains the same components as TRA and adds perceived control behavior as the third major construct in the prediction of intention and behavior ${ }^{(13)}$. Researchers have used TPB to predict intentions for physical activity $^{(14)}$, safer sex behavior ${ }^{(15)}$ and the intention of Muslim women to use oral contraceptives ${ }^{(1,16)}$. Both TRA and TPB have demonstrated predictive capabilities ${ }^{(17,18)}$.

\section{Method}

The study was conducted in the Madiun town administration using a community-based cross-sectional study design. The town is found in East Java Province, Indonesia. The sampling method used for the case group and the control group is fixed disease sampling, which is a sampling scheme based on the disease status of the subject, which is diseased or has no disease studied, while the subject's exposure status varies according to the subject's disease status ${ }^{(19)}$. The estimated number of cases and control groups uses a ratio of 1: 3 in each case. The case group in this study was the husband who was willing to be a vasectomy acceptor with a total of 85 married men while the control group was taken from a husband who did not use a vasectomy with a total of 248 married men. The total sample of this study was 323 married men. All of the questionnaires were prepared in Indonesian. A value of 1 to 4 was given for each strongly disagrees and strongly agrees with the answer for the questionnaire attitude, Subjective Norm and Perceived Behavioral Control. A value of 0 and 1 was given for each No and Yes answer for the Choice of contraception questionnaire. The attitude questionnaire consisted of 8 items. The Subjective Norm questionnaire consisted of 10 items. The Perceived Behavioral Control Questionnaire consisted of 10 items. Behavioral Intention Questionnaire consists of 5 items. All questionnaires used in this study were valid for use ${ }^{(20)}$. Data were collected from January to February 2020. Data were entered and analyzed using STATA. Tables, frequencies, and proportions are used to present the data. The association between dependent and independent variables was determined using the structural equation model. Logistic regression analysis was performed to control for potential confounders. Model fit was assessed by examining Chi-square (X2) statistic ( $\mathrm{P}$-value $>0.05$ is considered an acceptable fit), root mean square error of approximation (RMSEA; $<0.08$ is acceptable fit), comparative fit index (CFI; values close to 1 indicates goof fit), standardized root mean squared residual (SRMR; $<0.08$ is good fit) and coefficient of determination (CD, overall $\mathrm{R}$; values close to 1 indicate good fit) ${ }^{(21)}$.

\section{Results}

Characteristics of married men following the study are addressed in Table 1. Overall 323 married men were 45.5 years of age, where the average age of marriage was 26.5 years. The average age of a married man's wife is 40.5 years. $65.63 \%$ of married men have a high school education level and $0.62 \%$ are out of school. $33.44 \%$ of married men's jobs are entrepreneurs and $2.48 \%$ are farmers. $98.45 \%$ of married men show a positive attitude towards vasectomy. $58.82 \%$ of married men have sufficient Perceived Behavioral Control and $73.37 \%$ have sufficient intention for a vasectomy. $76.78 \%$ of married men choose the vasectomy contraceptive method.

Table 1 Sample characteristics for this study

\begin{tabular}{|l|c|}
\hline Characteristics of Respondents (n=323) & Frequency (\%) \\
\hline Age (mean) & 45.5 year \\
\hline Husband married age (mean) & 26.5 year \\
\hline Wife's age (mean) & 40.5 year \\
\hline Education level & $2(0.62 \%)$ \\
\hline No school & $19(5.88 \%)$ \\
\hline Elementary school & $57(17.65 \%)$ \\
\hline Middle School & $212(65.63 \%)$ \\
\hline High school & $33(10.22 \%)$ \\
\hline Higher education & \\
\hline Employment & $21(6.50 \%)$ \\
\hline Government employees & $96(29.72 \%)$ \\
\hline Private employees & $77(23.84 \%)$ \\
\hline Labor & $8(2.48 \%)$ \\
\hline Farmers & $13(4.02 \%)$ \\
\hline Driver & $108(33.44 \%)$ \\
\hline Enterpreneur & \multicolumn{2}{|l}{} \\
\hline
\end{tabular}




\begin{tabular}{|l|c|}
\hline Characteristics of Respondents (n=323) & Frequency (\%) \\
\hline Attitude & $5(1.55 \%)$ \\
\hline Positive & $318(98.45 \%)$ \\
\hline Negative & $82(25.39 \%)$ \\
\hline Subjective Norm & $214(66.25 \%)$ \\
\hline Less & $27(8.36 \%)$ \\
\hline Enough & $86(26.63 \%)$ \\
\hline Good & $190(58.82 \%)$ \\
\hline Perceived Behavioural Control & $48(14.86 \%)$ \\
\hline Less & $85(26.32 \%)$ \\
\hline Enough & $248(76.78 \%)$ \\
\hline Good & $7(2.17 \%)$ \\
\hline Intention & $237(73.37 \%)$ \\
\hline Less & $79(24.46 \%)$ \\
\hline Enough & \\
\hline Good & \\
\hline Choice of contraception & \\
\hline Vasectomy & \\
\hline Non vasectomy & \\
\hline
\end{tabular}

Figure 1 presents the standardized coefficients and significance levels obtained in the structural equation model using the maximum likelihood method as a parameter estimation procedure, as well as to determine the values of the explained variance $(\mathrm{R})$ for the variable empowerment and satisfaction at work. The path analysis showed an adequate adjustment of the final model, with $\mathrm{X} 2=.052$. Root mean square error of approximation was $0.00, \mathrm{CFI}=1.00$, SRMR 0.01 and $\mathrm{CD}=0.67$. Based on the data the model is valid. The results showed that "attitude" $(p=0.04)$ and "perceived behavioral control" $(p=<0.01)$ were positive predictive factors of intention married man to choose vasectomy for contraception (Table 2).

Table 2 Correlations among attitude, subjective norm, perceived behavioral control, intention and choice of contraception

\begin{tabular}{|l|c|c|c|}
\hline Variable & Std. Err. & $\mathbf{p}$ & [95\% Conf. Interval] \\
\hline Subjective norm $\rightarrow$ Intention & .05 & 0.72 & -.11 to .08 \\
\hline Attitude $\rightarrow$ Intention & .05 & 0.04 & .00 to .23 \\
\hline Perceived behavioural control $\rightarrow$ Intention & .41 & 0.00 & .75 to .91 \\
\hline Intention $\rightarrow$ Choice of contraception & .00 & 0.00 & .05 to .07 \\
\hline$X^{2}$ & & 0.52 \\
\hline RMSEA & & 0.00 \\
\hline CFI & \multicolumn{2}{|c|}{1.00} \\
\hline SRMR & \multicolumn{2}{|c|}{0.01} \\
\hline CD & \multicolumn{2}{|c|}{0.67} \\
\hline
\end{tabular}

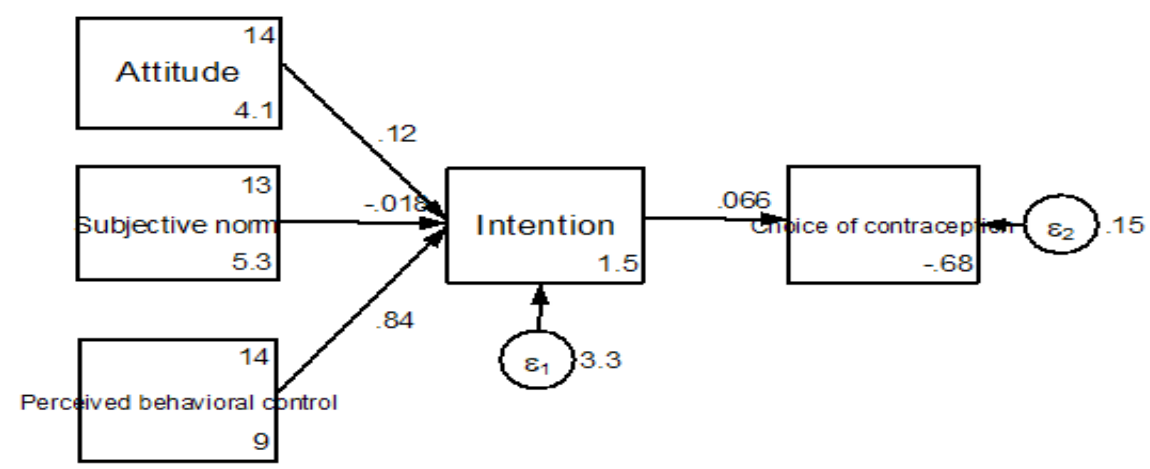

Figure 1: Association between attitude, subjective norm, perceived behavioral control, intention, and choice of contraception using a structural equation model. 


\section{Discussion}

This study applies the theory of planned behavior to the intention of married men to choose vasectomy as contraception to limit the number of children. This study found that low married men choose vasectomy. The low prevalence of vasectomy has also been shown by other studies ${ }^{(22,23)}$. This research has found the intention to limit the number of children affected by attitudes. Married men who participated in this study had negative attitudes towards vasectomy. In general, vasectomy is seen as one of the least preferred method of family planning and is associated with fear and weakness. Previous research found that there was a tendency to describe men who had been sterilized in negative terms, were often insulted, and even men who had positive experiences with vasectomy procedures chose not to disclose them to others in the community ${ }^{(24)}$. A recent study reports a list of factors that contribute to negative attitudes towards vasectomy, including the perceived negative impact on physical strength, ability to work and sexual performance, along with loss of masculinity, social status ${ }^{(25)}$. The findings from other studies on vasectomy are that the fear of decreasing libido in men will cause them to be unable to fulfill sexual needs adequately ${ }^{(26-28)}$.

Researchers have found $14.86 \%$ of perceived behavioral control of married men in either category. Poor understanding of the vasectomy procedure causes men to assume that vasectomy will pose certain health risks. For example, they equate vasectomy with castration and believe that the vasectomy procedure will have the same effect as castration in cattle. Shelton and Jacobson $^{(29)}$ argue that myth and misunderstanding play an important role in accepting vasectomy as a method of birth control. They argue that even when men and women know this method, their knowledge is filled with misunderstandings; especially that vasectomy is castration or weakening men. This finding is the following research ${ }^{(30-33)}$ the participants expressed concern that vasectomy would weaken their sexual ability. Social norms about family planning receive general attention, requiring an enabling environment to create comprehensive awareness and provision of information to increase knowledge and understanding of the various types of reproductive services available.

\section{Conclusion}

The theory of planned behavior can be used as a prediction for married men to choose vasectomy as contraception. The low of married men to choose vasectomy is positively influenced by attitude and perceived behavior control. The negative attitude of married men is closely related to physical strength, ability to work and sexual performance, along with loss of masculinity and social status.

Acknowledgments: We would like to thank for married men who have participated in the research.

Conflict of Interest: We do not have any conflict of interest.

\section{Source of Funding: None}

Ethical Clearance: The study was approved by the Institute of Health Sciences Surya Mitra Husada.

\section{References}

1. Peyman N, Oakley D. Effective contraceptive use: an exploration of theory-based influences. Health Educ Res [Internet]. 2009 Aug [cited 2020 Apr 7];24(4):575-85. Available from: http://www.ncbi. nlm.nih.gov/pubmed/19047649

2. Hoga LAK, Rodolpho JRC, Sato PM, Nunes MCM, Borges ALV. Adult men's beliefs, values, attitudes and experiences regarding contraceptives: A systematic review of qualitative studies. J Clin Nurs. 2014;23(7-8):927-39.

3. Sutinah S. Partisipasi laki-laki dalam program Keluarga Berencana di era masyarakat postmodern. Masyarakat, Kebud dan Polit [Internet]. 2017 Sep 20 [cited 2020 Aug 5];30(3):290. Available from: https://e-journal.unair.ac.id/MKP/article/ view/4116

4. Bunce A, Guest G, Searing H, Frajzyngier V, Riwa $\mathrm{P}$, Kanama J, et al. Factors affecting vasectomy acceptability in Tanzania. Int Fam Plan Perspect [Internet]. 2007 Mar [cited 2020 Apr 6];33(1):1321. Available from: http://www.ncbi.nlm.nih.gov/ pubmed/17462984

5. Cohen SI, Berger M, United Nations Population Fund. It takes 2 : partnering with men in reproductive \& sexual health. United Nations Population Fund; 2003. $46 \mathrm{p}$.

6. World Health Organization (WHO); Programming for male involvement in reproductive health. WHO. Geneva: World Health Organization; 2002.

7. Aradhya KW, Best K, Sokal DC. Recent developments in vasectomy. Vol. 330, British 
Medical Journal. 2005. p. 296-9.

8. Population Reference Bureau (PRB). Family Planning Worldwide 2002 Data Sheet - Population Reference Bureau [Internet]. [cited 2020 Apr 5]. Available from: https://www.prb.org/ familyplanningworldwide2002datasheet/

9. Kunz J, Bitzer J. [Pregnancy prevention from the viewpoint of women (1): Patient counseling by the general practitioner is rated as "very good". Women assess the pill as an effective and safe contraception method. A representative survey]. Prax (Bern 1994). 2000/08/26. 2000 Jul 1;89(27-28):1142-6.

10. Bianchi-Demicheli F, Perrin E, Bianchi PG, Dumont P, Lüdicke F, Campana A. Contraceptive practice before and after termination of pregnancy: a prospective study. Contraception [Internet]. 2003 Feb [cited 2020 Apr 7];67(2):107-13. Available from: http://www.ncbi.nlm.nih.gov/ pubmed/12586321

11. Ajzen I. The theory of planned behavior. Organ Behav Hum Decis Process. 1991 Dec 1;50(2):179211.

12. Ajzen I, Fishbein M. Understanding Attitudes and Predicting Social Behavior. Prentice-Hall, Englewood Cliffs, NJ. Pbk. ed. Englewood Cliffs N.J.: Prentice-Hall; 1980.

13. Noar SM. A health educator's guide to theories of health behavior [Internet]. Vol. 24, International Quarterly of Community Health Education. 2005 [cited 2020 Apr 7]. p. 75-92. Available from: http://www.ncbi.nlm.nih.gov/pubmed/17690053

14. Hagger MS, Chatzisarantis NLD, Biddle SJH. The influence of autonomous and controlling motives on physical activity intentions within the Theory of Planned Behaviour. Br J Health Psychol [Internet]. 2002 Sep [cited 2020 Apr 7];7(3):28397. Available from: http://www.ncbi.nlm.nih.gov/ pubmed/12614501

15. White KM, Terry DJ, Hogg MA. Safer Sex Behavior: The Role of Attitudes, Norms, and Control Factors. J Appl Soc Psychol [Internet]. 1994 Dec 1 [cited 2020 Apr 7];24(24):2164-92. Available from: http://doi.wiley.com/10.1111/j.1559-1816.1994. tb02378.x

16. Kridli SAO, Libbus K. Establishing reliability and validity of an instrument measuring Jordanian Muslim women's contraceptive beliefs [Internet]. Vol. 23, Health Care for Women International.
2002 [cited 2020 Apr 7]. p. 870-81. Available from: http://www.ncbi.nlm.nih.gov/pubmed/12487702

17. Godin G, Kok G. The theory of planned behavior: A review of its applications to health- related behaviors. Am J Heal Promot. 1996;11(2):87-98.

18. Albarracín D, Fishbein M, Johnson BT, Muellerleile PA. Theories of reasoned action and planned behavior as models of condom use: A meta-analysis. Psychol Bull. 2001;127(1):142-61.

19. Murti B. Desain dan Ukuran Sampel untuk Penelitian Kuantitatif dan Kualitatif di Bidang Kesehatan. Yogyakarta: Gadjah Mada University Press; 2013.

20. Satria G. Perilaku Pemilihan Metoda Kontrasepsi Vasektomi Pada Pria Pasangan Usia Subur Berdasarkan Theory of Planned Behavior (TPB) Di Kecamatan Kenjeran Surabaya. Universitas Airlangga; 2015.

21. Acock AC. Discovering structural equation modeling using Stata (Book, 2013) [WorldCat.org] [Internet]. Texas: Stata Press; 2013 [cited 2020 Apr 13]. Available from: https://www.worldcat.org/ title/discovering-structural-equation-modelingusing-stata/oclc/862057090

22. Borrero S, Moore CG, Creinin MD, Ibrahim SA. Low rates of vasectomy among minorities: a result of differential receipt of counseling? Am J Mens Health [Internet]. 2009 Sep 25 [cited 2020 Apr 10];4(3):243-9. Available from: http://www.ncbi. nlm.nih.gov/pubmed/19706674

23. Shongwe P, Ntuli B, Madiba S. Assessing the acceptability of vasectomy as a family planning option: A qualitative study with men in the Kingdom of Eswatini. Int J Environ Res Public Health [Internet]. 2019 Dec 2 [cited 2020 Apr 13];16(24). Available from: http://www.ncbi.nlm. nih.gov/pubmed/31861151

24. Scott B, Alam D, Raman S. Factors Affecting Acceptance of Vasectomy in Uttar Pradesh: Insights from Community-Based, Participatory Qualitative Research [Internet]. New York; 2011 May [cited 2020 Apr 13]. Available from: http://www.respondproject.org/pages/files/6_pubs/research-reports/ Study3-PEER-NSV-Report-May2011-FINAL.pdf

25. Perry B, Packer C, Quee DC, Zan T, Dulli L, Shattuck D. Recent Experiences and Lessons Learned in Vasectomy Programming in LowResource Settings: A Document Review The 
Evidence Project [Internet]. 2016 Mar [cited 2020 Apr 13]. Available from: https://www.fhi360. org/sites/default/files/media/documents/resourcevasectomy-lit-review-final.pdf

26. Withers M, Dworkin SL, Onono M, Oyier B, Cohen CR, Bukusi EA, et al. Men's Perspectives on Their Role in Family Planning in Nyanza Province, Kenya. Stud Fam Plann [Internet]. 2015 Jun 1 [cited 2020 Apr 13];46(2):201-15. Available from: http://www.ncbi.nlm.nih.gov/pubmed/26059990

27. Kabagenyi A, Jennings L, Reid A, Nalwadda G, Ntozi J, Atuyambe L. Barriers to male involvement in contraceptive uptake and reproductive health services: A qualitative study of men and women's perceptions in two rural districts in Uganda. Reprod Health [Internet]. 2014 Mar 5 [cited 2020 Apr 13];11(1):21. Available from: http://www.ncbi. nlm.nih.gov/pubmed/24597502

28. Dral AA, Tolani MR, Smet E, Luijn A van. Factors Influencing Male Involvement in Family Planning in Ntchisi District, Malawi - A Qualitative Study. Afr J Reprod Health [Internet]. 2018 Dec [cited 2020 Apr 13];22(4):35-43. Available from: http:// www.ncbi.nlm.nih.gov/pubmed/30632720

29. Jacobstein R. The kindest cut: Global need to increase vasectomy availability. Vol. 3, The Lancet Global Health. Elsevier Ltd; 2015. p. e733-4.

30. Shattuck D, Perry B, Packer C, Quee DC. A review of 10 years of vasectomy programming and research in low-resource settings. Vol. 4, Global Health Science and Practice. Johns Hopkins University Press; 2016. p. 647-60.

31. Kısa S, Savaş E, Zeyneloğlu S, Dönmez S. Opinions and Attitudes About Vasectomy of Married Couples Living in Turkey. Am J Mens Health [Internet]. 2017 May 1 [cited 2020 Nov 11];11(3):531-41. Available from: http://journals.sagepub.com/doi/ full/10.1177/1557988315620275

32. Adongo PB, Tapsoba P, Phillips JF, Tabong PTN, Stone A, Kuffour E, et al. "If you do vasectomy and come back here weak, i will divorce you": A qualitative study of community perceptions about vasectomy in Southern Ghana. BMC Int Health Hum Rights. 2014 May 8;14(1).

33. Christiana O, Sonachi C, Chinomso* N. Knowledge and attitude of men about vasectomy as a method of family planning among married men working in Babcock University, Ogun state, Nigeria. Int J Nurs Midwifery. 2015 Mar 31;7(3):30-5. 